\title{
ScIDoC
}

International Journal of Dentistry and Oral Science (IJDOS)

ISSN: 2377-8075

\section{Retrospective CBCT Analysis Of Root Canal Morphology Of Mandibular Incisors In Indian Sub Population}

Research Article

Nivedhitha ${ }^{1 *}$, Swarna ${ }^{2}$, Pradeep ${ }^{3}$

${ }^{1}$ Professor and Head, Department of Conservative Dentistry and Endodontics, Saveetha Dental College and Hospitals, Saveetha Institute of Medical and Technical Sciences, Saveetha University 162, Poonamallee High Road, Chennai 600077, Tamilnadu, India.

${ }^{2}$ Department of Conservative Dentistry \& Endodontics, Saveetha Dental College and Hospitals, Saveetha Institute of Medical and Technical Sciences, Saveetha University, Chennai, India.

${ }^{3}$ Associate Professor, Department of Conservative Dentistry and Endodontics, Saveetha Dental College and Hospitals, Saveetha Institute of Medical and Technical Sciences, Saveetha University, Chennai 600077, Tamilnadu, India.

\section{Abstract}

Aim: The aim of the study was to analyze the root canal morphology of permanent mandibular incisors in Indian subpopulation using cone beam computed tomography (CBCT).

Materials and Methods: A total of 100 patients with 400 well $\square$ developed mandibular incisors with out attrition were evaluated. CBCT images were retrieved from the database of patients who received treatment at Saveetha Dental College. The following parameters were evaluated using CBCT: (1) the number of roots; (2) the number of canals; (3) canal configuration according to Vertucci's classification; (4) length of the tooth (5) point of bifurcation of canal from the incisal edge.

Results: The data collected consisted of 53\% males and $47 \%$ females. The canal morphology was analyzed according to Vertucci classification and Type I configuration was observed in $64.5 \%$, Type III in $32.5 \%$ and Type II in $0.03 \%$ of the population studied. $71 \%$ of mandibular central incisors and $58 \%$ of mandibular lateral incisors had Type I configuration, $29 \%$ of mandibular central incisors and $36 \%$ of mandibular lateral incisors had Type III and only $0.06 \%$ of mandibular lateral incisors had Type II configuration. In the teeth with two canals, Type III configuration was most common. There were no statistically significant differences found between the mandibular central and lateral incisors central and lateral incisors in terms of length of the teeth, type of vertucci classification or point of bifurcation $(\mathrm{p}>0.05)$.

Conclusion: CBCT can be of great use in locating the accessory canal and analyzing canal configurations in mandibular incisors. Knowledge of level of bifurcation of the canal can aid in effectively identifying the extra canals and promote appropriate disinfection of the root canal system.

Keywords: Canal Configuration; Cone Beam Computed Tomography; Level Of Bifurcation; Mandibular Incisors; Vertucci Classification.

\section{Introduction}

The knowledge on the anatomical variations of the root canal system would aid the clinician to achieve greater clinical success with adequate disinfection of the canal intricacies of the root canal system [1]. The single canals diverging, lateral or accessory canals, isthmuses and c shaped canals are challenging scenarios where skill negotiation and disinfection with irrigant activation systems play a pivotal role [2]. Tooth development is moderated by various epithelial mesenchymal interactions any disturbance during the developmental stages might result in morphological and functional abnormality [3]. Weine et al studied the root ca-

\section{*Corresponding Author}

Nivedhitha,

Professor and Head, Department of Conservative Dentistry and Endodontics, Saveetha Dental College and Hospitals, Saveetha Institute of Medical and Technical Sciences, Saveetha University 162, Poonamallee High Road, Chennai 600077, Tamilnadu, India.

Tel: +919840912367

Email Id: nivedhitha@saveetha.com

Received: May 05, 2021

Accepted: May 28, 2021

Published: May 30, 2021

Citation: Nivedhitha, Swarna, Pradeep. Retrospective CBCT Analysis Of Root Canal Morphology Of Mandibular Incisors In Indian Sub Population. Int J Dentistry Oral Sci. 2021;08(05):2591-2596. doi: http://dx.doi.org/10.19070/2377-8075-21000507

Copyright: Nivedhitha 2021 . This is an open-access article distributed under the terms of the Creative Commons Attribution License, which permits unrestricted use, distribution and reproduction in any medium, provided the original author and source are credited. 
nal morphology of single rooted teeth [4]. Vertucci classification has been popularly advocated since 1984 to address different root canal morphologies [5, 6]. Recently a new description of the position and configuration of accessory and chamber canals was proposed $[7,8]$.

With the advent of advanced imaging systems like CBCT (Cone beam Computed Tomography), the identification of aberrant anomalies, missed canals, resorptions, canal trajectories, their angle of curvature and path of apical exit, the ramifications in the furcal and apical third of the root are precisely identified [9]. Unlike periapical radiography, CBCT provided a three dimensional image of the teeth at less radiation than traditional Computed tomography [6]. The primary cause of root canal failure was due to insufficient cleaning and shaping due to isthmuses or missed canals [10]. There were varied diversities in the root canals of lower anteriors based on gender and type of population studied [11].

Permanent mandibular incisors usually present with a single root with a large oval canal or lateral or accessory canals usually branching from the coronal or middle third of the root canal. The prevalence rate of missed canals in mandibular central incisors were $12.2 \%$ and mandibular lateral incisors were $17.4 \%$, respectively [12]. This clearly demonstrates the ignorance of treating extra canals in cases of lower anteriors. Knowledge on anatomy not only aids in negotiating canals, but it is also very useful in avoiding perforations during access cavity preparations as the width of the tooth is wider buccolingually than mesiodistally [13].

Previously our team has a rich experience in working on various research projects across multiple disciplines [14-28] Now the growing trend in this area motivated us to pursue this project. The objective of this retrospective analytical study was to analyze root canal morphology of permanent mandibular incisors, average length of the tooth and the point of bifurcation of canal from the incisal edge of the tooth.

\section{Materials and Methods}

A total of 400 mandibular central and lateral incisors (200 central and 200 lateral incisors) were evaluated. CBCT images were retrieved from the database of Saveetha Dental college from 2020 to 2021, Mandibular central and lateral incisors with fully developed roots and closed apices with no signs of attrition or restoration were included for CBCT analysis. The CBCT's taken for orthodontic treatment considering the age group of 18-30 years were chosen for the study to avoid attrited teeth. The sample chosen for this study was similar to precious CBCT retrospective studies $[29,30]$.
Previously initiated or root canal treated teeth, calcified teeth, teeth with internal or external resorptions or radiopaque fillings [31], or distorted images on CBCT were excluded. The CBCT machine used in this in vivo retrospective study was CBCT dental imaging system (Galileos, Sirona system, Bensheim, Germany) operating at $98 \mathrm{kvp}$ and $5-15 \mathrm{~mA} 17.5 \square$ s exposure time, and $0.25 \square \mathrm{mm}$ voxel size. Serial axial, coronal, and sagittal sections were acquired to analyze the morphology of teeth anatomically [32]. The same Endodontist assessed the CBCT images twice, with a 2 week interval in between each assessment.

The following parameters were evaluated:

- Number of roots.

- Number of canals.

- Canal configurations according to Vertucci classification [5].

- Type I: Only a single canal originates from pulp chamber to the apex.

- Type II: Originally there are two separate canals that leave the pulp chamber, but unite and have a common exit.

- Type III: It begins as one canal from pulp chamber, divides within root but unites to form a single canal before exit.

- Type IV: There are two distinct canals that arise from pulp chamber to the apex.

- Type V: There is a single canal originating from the pulp chamber but dividing into two distinct canals with separate apical foramina.

- Level of point of bifurcation from the incisal edge (Figure1,3,4).

Statistical analysis was carried out using SPSS 23.0 version. Frequency distribution of male and female patients for the canal configuration based on Vertucci classification, frequency distribution of mandibular anteriors was carried out based on vertucci classification. The association between root length and point of bifurcation based on gender, tooth type and the canal configuration was carried out using Chi-square test (Figure 1,2,3,4).

\section{Results}

The data collected consisted of $53 \%$ males and $47 \%$ females (Table 1) (Figure 2). The canal morphology was analyzed according to Vertucci classification and Type I configuration was observed in $64.5 \%$, Type III in $32.5 \%$ and Type II in $0.03 \%$ of the population studied (Table 2, 3) (Figure 3). 71\% of mandibular central incisors and $58 \%$ of mandibular lateral incisors had Type I configuration, $29 \%$ of mandibular central incisors and $36 \%$ of mandibular lateral incisors had Type III configuration and only $0.06 \%$ of mandibular lateral incisors had Type II configuration (Figure

Table 1. It represents the distribution of male and female patients mandibular anterior for the canal configuration based on vertucci classification, most of the mandibular anteriors had type I canal configuration, followed by type III canal configuration.

\begin{tabular}{|c|c|c|c|c|c|}
\hline \multicolumn{2}{|c|}{} & \multicolumn{2}{|c|}{ VERTUCCI CLASSIFICATION } & \multirow{2}{*}{ Total } \\
\cline { 3 - 5 } \multicolumn{2}{|c|}{} & $\mathbf{1}$ & $\mathbf{1 - F e b}$ & $\mathbf{1 / 2 / 2 0 0 1}$ & \\
\hline \multirow{2}{*}{ GENDER } & MALE & 135 & 8 & 69 & 212 \\
\cline { 2 - 5 } & FEMALE & 123 & 4 & 61 & 188 \\
\hline \multicolumn{2}{|c|}{ Total } & 258 & 12 & 130 & $` 400$ \\
\hline
\end{tabular}


3,4). Type III configuration was the most common configuration when there was an extra canal encountered in mandibular anteriors. There were no statistically significant differences found between the mandibular central and lateral incisors central and lateral incisors in terms of length of the teeth, type of vertucci classification or point of bifurcation $(\mathrm{p}>0.05)$. Average length of tooth and the level of bifurcation of mandibular anteriors were measured from the incisal edge. Average length of mandibular central and lateral incisors was $19.7 \mathrm{~mm}$ and $18.9 \mathrm{~mm}$ respectively.
The level of bifurcation for mandibular central and lateral incisors were $9.8 \mathrm{~mm}$ and $9.5 \mathrm{~mm}$ respectively (Figure 1).

\section{Discussion}

Various retrospective studies have been conducted for analysing the diversity of the root canal system. Based on available literature, this is the first kind of study analysing the level of bifurcation of the extra canals of the mandibular central and lateral incisor in the

Table 2. It represents the distribution of Tooth type (mandibular central and lateral incisors) and Root canal configuration. Both mandibular central and lateral incisors had predominantly Type I Vertucci classification followed by Type III.

\begin{tabular}{|c|c|c|c|c|c|}
\hline \multicolumn{2}{|c|}{} & \multicolumn{2}{|c|}{ VERTUCCI CLASSIFICATION } & \multirow{2}{*}{ Total } \\
\cline { 3 - 6 } \multicolumn{2}{|c|}{} & $\mathbf{1}$ & $\mathbf{1 - F e b}$ & $\mathbf{1 / 2 / 2 0 0 1}$ & \\
\hline \multirow{3}{*}{$\begin{array}{c}\text { TOOTH } \\
\text { NUMBER }\end{array}$} & 31 & 71 & 0 & 29 & 100 \\
\cline { 2 - 5 } & 32 & 58 & 6 & 36 & 100 \\
\cline { 2 - 5 } & 41 & 71 & 0 & 29 & 100 \\
\cline { 2 - 5 } & 42 & 58 & 6 & 36 & 100 \\
\hline \multicolumn{2}{|c|}{ Total } & 258 & 12 & 130 & 400 \\
\hline
\end{tabular}

Table 3. Average length of tooth and the level of bifurcation of mandibular anteriors from the incisal edge. Average length of mandibular central and lateral incisors was $19.7 \mathrm{~mm}$ and $18.9 \mathrm{~mm}$ respectively. The level of bifurcation for mandibular central and lateral incisors were $9.8 \mathrm{~mm}$ and $9.5 \mathrm{~mm}$ respectively.

\begin{tabular}{|c|c|c|c|}
\hline \multicolumn{2}{|c|}{ TOOTH NUMBER } & ROOT LENGTH & LEVEL OF BIFURCATION \\
\hline \multirow{4}{*}{31} & Mean & 19.7069 & 9.8724 \\
\cline { 2 - 4 } & $\mathrm{N}$ & 29 & 29 \\
\cline { 2 - 4 } & Std. Deviation & 1.16126 & 1.17925 \\
\hline \multirow{4}{*}{32} & Mean & 18.9119 & 9.5571 \\
\cline { 2 - 4 } & $\mathrm{N}$ & 42 & 42 \\
\cline { 2 - 4 } & Std. Deviation & 1.67233 & 1.26590 \\
\hline \multirow{4}{*}{41} & Mean & 19.7414 & 9.8138 \\
\cline { 2 - 4 } & $\mathrm{N}$ & 29 & 29 \\
\cline { 2 - 4 } & Std. Deviation & 1.16971 & 1.26399 \\
\hline \multirow{4}{*}{42} & Mean & 18.9405 & 9.5548 \\
\cline { 2 - 4 } & $\mathrm{N}$ & 42 & 42 \\
\cline { 2 - 4 } & Std. Deviation & 1.62001 & 1.33420 \\
\hline \multirow{4}{*}{ Total } & Mean & 19.2521 & 9.6732 \\
\cline { 2 - 4 } & N & 142 & 142 \\
\cline { 2 - 4 } & Std. Deviation & 1.50699 & 1.26390 \\
\hline
\end{tabular}

Figure 1. CBCT radiographic Axial sections showing presence of two canals(A), Sagittal sections of CBCT revealed Vertucci type I (B) and Type III (C,D,E) configurations and also the level of bifurcation measured from the incisal edge (C,D,E).

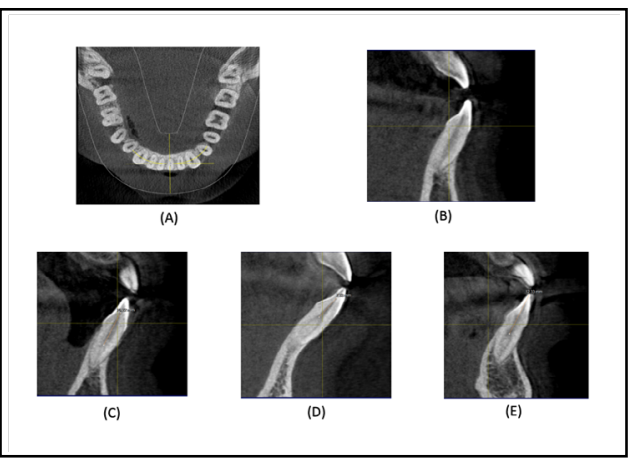


Figure 2. Graphical representation showing association between Gender, Root length and point of bifurcation from the incisal edge, chi square showed no statistical significant difference $(p>0.05)$.

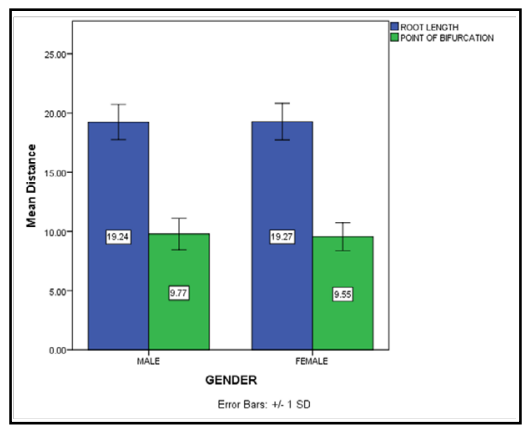

Figure 3. Graphical representation showing association between Root length and point of bifurcation from the incisal edge for Vertucci Type II and Type III classification. Chi square showed no statistical significant differences ( $p>0.05)$.

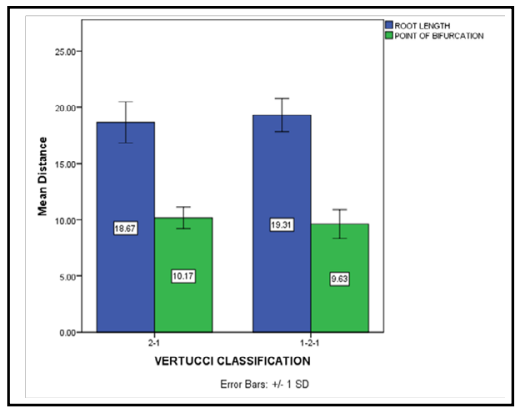

Figure 4. Graphical representation showing association between Tooth type( mandibular central or lateral incisor), Root length and point of bifurcation from the incisal edge. Chi square showed no statistical significant differences ( $p>0.05$ ).

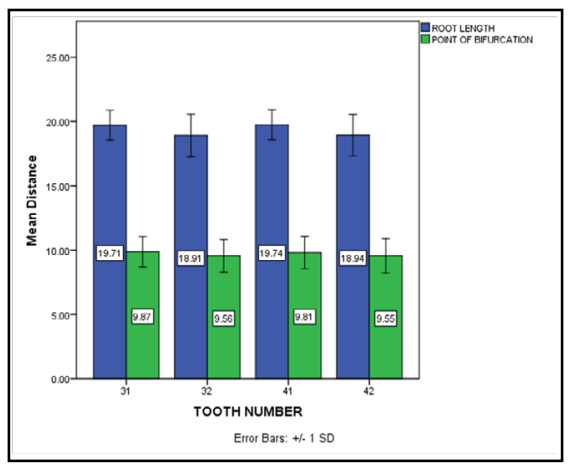

South Indian population. Our institution is passionate about high quality evidence based research and has excelled in various fields $[18,33-42]$ that innovated us to undertake this evaluative study.

Invito studies have used clearing techniques and micro CT for studying the diversity of root canal patterns [43]. Clinically the most appropriate technique for identifying extra canals was with the aid of CBCT. Different CBCT devices and softwares with varying parameters have been used in retrospective studies. Highresolution CBCT with voxel size smaller than $0.2 \mathrm{~mm}$ has better clarity of CBCT for endodontic purposes [44, 45]. Failures in treating lower anteriors are mainly due to missed lingual canals which turn necrotic and release toxins that reach the periapical region through lateral or accessory canals [46]. The lingual shelf of dentin must be removed and the lingual part of the pulp chamber should be adequately widened to gain access for negotiating extra canals in mandibular anteriors [47].

Few studies have shown that the incidence of second canal in mandibular incisors was greater in females than males [48, 49]. There was no association between gender and the type of canal configuration in our study which was similar to results of Saati et al [32]. The average length of mandibular incisors were studied to be $22.2 \mathrm{~mm}$ and $21.4 \mathrm{~mm}$ for mandibular central and lateral incisors respectively. The average distance from the incisal edge to the roof of the pulp chamber was studied to be $4 . .41$ and $4.85 \mathrm{~mm}$ for mandibular central and lateral incisors respectively [50].

The morphological characteristics of the North East Indian population have reported $63.75 \%$ teeth with single canal (Type I Vertucci classification), $36.25 \%$ prevalence of second canal in mandibular anteriors and Type III more common than type II which was similar to our study results. $64 \%$ of bifurcations originated at middle third and $23.3 \%$ at cervical third of the root canals [51]. Type I vertucci classification was significantly higher for mandibular incisors worldwide since studies from various countries proved the same [11, 29, 30, 46, 52].

The limitations of this study include a small sample size and the data collection was from a restricted area with which strong conclusions can not be drawn. Also very narrow age groups of 18 to 30 years of age were selected for the study to avoid attrition. But 
this cannot be clinically translatable for attrited teeth in elderly individuals. Similar studies with large sample sizes from various parts of the country will be more appropriate in analyzing the incidence of extra canals and bifurcation patterns of the mandibular incisors.

\section{Acknowledgement \& Declaration}

We would like to acknowledge my mentors and guide for helping me in data collection and analysis and better understanding of the subject to comparatively analyze the root canal morphology of mandibular incisors.

\section{Conclusion}

With in the limitations of this study, permanent mandibular incisors presented with more than one canal in about $35.5 \%$ of cases. Mandibular central and lateral incisors showed no significant difference between genders with regard to length of the tooth, number of canals and canals configurations. CBCT is the ideal for critically analyzing the root canal system.

\section{References}

[1]. Karobari MI, Parveen A, Mirza MB, Makandar SD, Nik Abdul Ghani NR, Noorani TY, et al. Root and Root Canal Morphology Classification Systems. Int J Dent. 2021 Feb 19;2021:6682189. Pubmed PMID: 33679981.

[2]. Nagendrababu V, Jayaraman J, Suresh A, Kalyanasundaram S, Neelakan$\tan$ P. Effectiveness of ultrasonically activated irrigation on root canal disinfection: a systematic review of in vitro studies. Clin Oral Investig. 2018 Mar;22(2):655-670. Pubmed PMID: 29372445.

[3]. Shrestha A, Marla V, Shrestha S, Maharjan IK. Developmental anomalies affecting the morphology of teeth-a review. RSBO Revista Sul-Brasileira de Odontologia. 2015;12(1):68-78.

[4]. Cohn SA. Endodontic Therapy 6th Edition: By Franklin S. Weine.

[5]. Vertucci FJ. Root canal anatomy of the human permanent teeth. Oral Surg Oral Med Oral Pathol. 1984 Nov;58(5):589-99. Pubmed PMID: 6595621.

[6]. Borges CC, Estrela C, Decurcio DA, PÉcora JD, Sousa-Neto MD, RossiFedele G. Cone-beam and micro-computed tomography for the assessment of root canal morphology: a systematic review. Braz Oral Res. 2020 Jun 19;34:e056. Pubmed PMID: 32578799.

[7]. Ahmed HMA, Ibrahim N, Mohamad NS, Nambiar P, Muhammad RF, Yusoff $\mathrm{M}$, et al. Application of a new system for classifying root and canal anatomy in studies involving micro-computed tomography and cone beam computed tomography: Explanation and elaboration. Int Endod J. 2021 Feb 2. Pubmed PMID: 33527452.

[8]. Ahmed HMA, Dummer PMH. Advantages and Applications of a New System for Classifying Roots and Canal Systems in Research and Clinical Practice. Eur Endod J. 2017 Dec 21;3(1):9-17. Pubmed PMID: 32161850.

[9]. Patel S, Kanagasingam S, Mannocci F. Cone beam computed tomography (CBCT) in endodontics. Dent Update. 2010 Jul-Aug;37(6):373-9. Pubmed PMID: 20929151.

[10]. von Arx T. Frequency and type of canal isthmuses in first molars detected by endoscopic inspection during periradicular surgery. Int Endod J. 2005 Mar;38(3):160-8. Pubmed PMID: 15743419.

[11]. Herrero-Hernández S, López-Valverde N, Bravo M, Valencia de Pablo Ó, Peix-Sánchez M, Flores-Fraile J, et al. Root Canal Morphology of the Permanent Mandibular Incisors by Cone Beam Computed Tomography: A Systematic Review. Applied Sciences. 2020 Jan;10(14):4914.

[12]. Baruwa AO, Martins JNR, Meirinhos J, Pereira B, Gouveia J, Quaresma SA, et al. The Influence of Missed Canals on the Prevalence of Periapical Lesions in Endodontically Treated Teeth: A Cross-sectional Study. J Endod. 2020 Jan;46(1):34-39.e1. Pubmed PMID: 31733814.

[13]. Estrela C, Decurcio DA, Rossi-Fedele G, Silva JA, Guedes OA, Borges ÁH. Root perforations: a review of diagnosis, prognosis and materials. Braz Oral Res. 2018 Oct 18;32(suppl 1):e73. Pubmed PMID: 30365614.

[14]. Govindaraju L, Gurunathan D. Effectiveness of Chewable Tooth Brush in Children-A Prospective Clinical Study. J Clin Diagn Res. 2017 Mar;11(3):ZC31-ZC34. Pubmed PMID: 28511505.

[15]. Christabel A, Anantanarayanan P, Subash P, Soh CL, Ramanathan M, Muth- usekhar MR, et al. Comparison of pterygomaxillary dysjunction with tuberosity separation in isolated Le Fort I osteotomies: a prospective, multi-centre, triple-blind, randomized controlled trial. Int J Oral Maxillofac Surg. 2016 Feb;45(2):180-5. Pubmed PMID: 26338075.

[16]. Soh CL, Narayanan V. Quality of life assessment in patients with dentofacial deformity undergoing orthognathic surgery--a systematic review. Int J Oral Maxillofac Surg. 2013 Aug;42(8):974-80. Pubmed PMID: 23702370.

[17]. Mehta M, Deeksha, Tewari D, Gupta G, Awasthi R, Singh H, et al. Oligonucleotide therapy: An emerging focus area for drug delivery in chronic inflammatory respiratory diseases. Chem Biol Interact. 2019 Aug 1;308:206215. Pubmed PMID: 31136735.

[18]. Ezhilarasan D, Apoorva VS, Ashok Vardhan N. Syzygium cumini extract induced reactive oxygen species-mediated apoptosis in human oral squamous carcinoma cells. J Oral Pathol Med. 2019 Feb;48(2):115-121. Pubmed PMID: 30451321.

[19]. Campeau PM, Kasperaviciute D, Lu JT, Burrage LC, Kim C, Hori M, et al. The genetic basis of DOORS syndrome: an exome-sequencing study. Lancet Neurol. 2014 Jan;13(1):44-58. Pubmed PMID: 24291220.

[20]. Kumar S, Sneha S. Knowledge and awareness regarding antibiotic prophylaxis for infective endocarditis among undergraduate dental students. Asian Journal of Pharmaceutical and Clinical Research. 2016;154.

[21]. Christabel SL, Gurunathan D. Prevalence of type of frenal attachment and morphology of frenum in children, Chennai, Tamil Nadu. World J Dent. 2015 Oct;6(4):203-7.

[22]. Kumar S, Rahman RE. Knowledge, awareness, and practices regarding biomedical waste management among undergraduate dental students. Asian Journal of Pharmaceutical and Clinical Research. 2017;10(8):341.

[23]. Sridharan G, Ramani P, Patankar S. Serum metabolomics in oral leukoplakia and oral squamous cell carcinoma. J Cancer Res Ther. 2017 JulSep;13(3):556-561. Pubmed PMID: 28862226.

[24]. Ramesh A, Varghese SS, Doraiswamy JN, Malaiappan S. Herbs as an antioxidant arsenal for periodontal diseases. J Intercult Ethnopharmacol. 2016 Jan 27;5(1):92-6. Pubmed PMID: 27069730.

[25]. Thamaraiselvan M, Elavarasu S, Thangakumaran S, Gadagi JS, Arthie T. Comparative clinical evaluation of coronally advanced flap with or without platelet rich fibrin membrane in the treatment of isolated gingival recession. J Indian Soc Periodontol. 2015 Jan-Feb;19(1):66-71. Pubmed PMID: 25810596.

[26]. Thangaraj SV, Shyamsundar V, Krishnamurthy A, Ramani P, Ganesan K, Muthuswami M, et al. Molecular Portrait of Oral Tongue Squamous Cell Carcinoma Shown by Integrative Meta-Analysis of Expression Profiles with Validations. PLoS One. 2016 Jun 9;11(6):e0156582. Pubmed PMID: 27280700.

[27]. Ponnulakshmi R, Shyamaladevi B, Vijayalakshmi P, Selvaraj J. In silico and in vivo analysis to identify the antidiabetic activity of beta sitosterol in adipose tissue of high fat diet and sucrose induced type- 2 diabetic experimental rats. Toxicol Mech Methods. 2019 May;29(4):276-290. Pubmed PMID: 30461321.

[28]. Ramakrishnan M, Bhurki M. Fluoride, Fluoridated Toothpaste Efficacy And Its Safety In Children-Review. International Journal of Pharmaceutical Research. 2018 Oct 1;10(04):109-14.

[29]. Silva EJ, Nejaim Y, Silva AV, Haiter-Neto F, Cohenca N. Evaluation of root canal configuration of mandibular molars in a Brazilian population by using cone-beam computed tomography: an in vivo study. J Endod. 2013 Jul;39(7):849-52. Pubmed PMID: 23791250

[30]. Sroczyk-Jaszczyńska M, Kołecki J, Lipski M, Puciło M, Wilk G, Falkowski A, et al. A study of the symmetry of roots and root canal morphology in mandibular anterior teeth using cone-beam computed tomographic imaging in a Polish population. Folia Morphol (Warsz). 2020;79(4):835-844. Pubmed PMID: 31802476

[31]. Schulze R, Heil U, Gross D, Bruellmann DD, Dranischnikow E, Schwanecke U, et al. Artefacts in CBCT: a review. Dentomaxillofac Radiol. 2011 Jul;40(5):265-73. Pubmed PMID: 21697151.

[32]. Saati S, Shokri A, Foroozandeh M, Poorolajal J, Mosleh N. Root Morphology and Number of Canals in Mandibular Central and Lateral Incisors Using Cone Beam Computed Tomography. Braz Dent J. 2018 MayJun;29(3):239-244. Pubmed PMID: 29972448.

[33]. Vijayashree Priyadharsini J. In silico validation of the non-antibiotic drugs acetaminophen and ibuprofen as antibacterial agents against red complex pathogens. J Periodontol. 2019 Dec;90(12):1441-1448. Pubmed PMID: 31257588.

[34]. J PC, Marimuthu T, C K, Devadoss P, Kumar SM. Prevalence and measurement of anterior loop of the mandibular canal using CBCT: A cross sectional study. Clin Implant Dent Relat Res. 2018 Aug;20(4):531-534. Pubmed PMID: 29624863.

[35]. Ramesh A, Varghese S, Jayakumar ND, Malaiappan S. Comparative estimation of sulfiredoxin levels between chronic periodontitis and healthy patients 
- A case-control study. J Periodontol. 2018 Oct;89(10):1241-1248. Pubmed PMID: 30044495.

[36]. Ramadurai N, Gurunathan D, Samuel AV, Subramanian E, Rodrigues SJL. Effectiveness of 2\% Articaine as an anesthetic agent in children: randomized controlled trial. Clin Oral Investig. 2019 Sep;23(9):3543-3550. Pubmed PMID: 30552590.

[37]. Sridharan G, Ramani P, Patankar S, Vijayaraghavan R. Evaluation of salivary metabolomics in oral leukoplakia and oral squamous cell carcinoma. J Oral Pathol Med. 2019 Apr;48(4):299-306. Pubmed PMID: 30714209.

[38]. Mathew MG, Samuel SR, Soni AJ, Roopa KB. Evaluation of adhesion of Streptococcus mutans, plaque accumulation on zirconia and stainless steel crowns, and surrounding gingival inflammation in primary molars: randomized controlled trial. Clin Oral Investig. 2020 Sep;24(9):3275-3280. Pubmed PMID: 31955271

[39]. Samuel SR. Can 5-year-olds sensibly self-report the impact of developmental enamel defects on their quality of life? Int J Paediatr Dent. 2021 Mar;31(2):285-286. Pubmed PMID: 32416620.

[40]. R H, Ramani P, Ramanathan A, R JM, S G, Ramasubramanian A, et al. CYP2 C9 polymorphism among patients with oral squamous cell carcinoma and its role in altering the metabolism of benzo[a]pyrene. Oral Surg Oral Med Oral Pathol Oral Radiol. 2020 Sep;130(3):306-312. Pubmed PMID: 32773350

[41]. Chandrasekar R, Chandrasekhar S, Sundari KKS, Ravi P. Development and validation of a formula for objective assessment of cervical vertebral bone age. Prog Orthod. 2020 Oct 12;21(1):38. Pubmed PMID: 33043408.

[42]. Vijayashree Priyadharsini J, Smiline Girija AS, Paramasivam A. In silico analysis of virulence genes in an emerging dental pathogen A. baumannii and related species. Arch Oral Biol. 2018 Oct;94:93-98. Pubmed PMID: 30015217.

[43]. Nogueira BM, Nogueira BC, Fagundes NC, Menezes TO, Lima RR, Brandão JM. Root and canal morphology of permanent mandibular inci- sors. Int J Odontostomat. 2017;11(1):95-100.

[44]. Spin-Neto R, Gotfredsen E, Wenzel A. Impact of voxel size variation on CBCT-based diagnostic outcome in dentistry: a systematic review. J Digit Imaging. 2013 Aug;26(4):813-20. Pubmed PMID: 23254628.

[45]. Damstra J, Fourie Z, Huddleston Slater JJ, Ren Y. Accuracy of linear measurements from cone-beam computed tomography-derived surface models of different voxel sizes. Am J Orthod Dentofacial Orthop. 2010 Jan;137(1):16. e1-6; discussion 16-7. Pubmed PMID: 20122425.

[46]. Valenti-Obino F, Di Nardo D, Quero L, Miccoli G, Gambarini G, Testarelli L, et al. Symmetry of root and root canal morphology of mandibular incisors: A cone-beam computed tomography study in vivo. J Clin Exp Dent. 2019 Jun 1;11(6):e527-e533. Pubmed PMID: 31346372.

[47]. EZ AA, Mohammadi Z, Tabrizizadeh M. Root canal morphology of human mandibular incisors in Yazd Province.

[48]. Verma GR, Bhadage C, Bhoosreddy AR, Vedpathak PR, Mehrotra GP, Nerkar AC, et al. Cone Beam Computed Tomography Study of Root Canal Morphology of Permanent Mandibular Incisors in Indian Subpopulation. Pol J Radiol. 2017 Jul 7;82:371-375. Pubmed PMID: 28794810.

[49]. Liu J, Luo J, Dou L, Yang D. CBCT study of root and canal morphology of permanent mandibular incisors in a Chinese population. Acta Odontol Scand. 2014 Jan;72(1):26-30. Pubmed PMID: 24255962.

[50]. Kurumboor K, Tarun GS, Chandra RV, Vasundhara V, Aruna CN. Root Canal Morphology of Human Permanent Mandibular Anterior Teeth in an Indian Population using CBCT.

[51]. Boruah LC, Bhuyan AC. Morphologic characteristics of root canal of mandibular incisors in North-East Indian population: An in vitro study. J Conserv Dent. 2011 Oct;14(4):346-50. Pubmed PMID: 22144800.

[52]. Al-Qudah AA, Awawdeh LA. Root canal morphology of mandibular incisors in a Jordanian population. Int Endod J. 2006 Nov;39(11):873-7. Pubmed PMID: 17014525 . 